\title{
AQUA MEDIATED ONE POT FACILE SYNTHESIS OF NOVEL THIOXO-1,2,4-TRIAZIN-5(2H)-ONE AND [1,2,4] TRIAZINO[5,6-b]INDOLE DERIVATIVES AND THEIR BIOLOGICAL ACTIVITIES
}

\author{
HARSHITA SACHDEVA ${ }^{a *}$, DIKSHA DWIVEDI ${ }^{a}$, HAR LAL SINGH ${ }^{a}$, KANTI PRAKASH SHARMA ${ }^{b}$ \\ ${ }^{a}$ Department of Chemistry, Faculty of Engineering and Technology, \\ ${ }^{b}$ Department of Biotechnology, Faculty of Arts, Science and Commerce, \\ Mody Institute of Technology and Science, Lakshmangarh- 332311(Sikar), Rajasthan, India \\ (Received: November 22, 2011 - Accepted: May 3, 2012)
}

\begin{abstract}
Rapid and highly efficient one pot green chemical synthesis of substituted 6-(2-aminophenyl)-4-(4-substitutedphenyl)-3-thioxo-3,4-dihydro-1,2,4-triazin$5(2 H)$-one and 8 -substituted-3,5-dihydro- $2 H$-[1,2,4]triazino[5,6-b]indole is carried out in aqueous medium under microwave irradiation. Improved synthesis of potent bioactive Schiff and N-Mannich bases of hexahydro-1H-indole-2,3-dione is also reported. The title compounds are easily accessible by various approaches; even waste free approaches have been developed. The operational simplicity, environmentally benign conditions and high yield achieved in a very short reaction time are major benefits that meet the requirements of green production, including saving energy and high efficiency. The results obtained under microwaves are compared with that of conventional heating. Structural assignments are based on spectroscopic data. Compounds have also been screened for antibacterial and antifungal activities.
\end{abstract}

Keywords: Aqueous media, Microwave, Thioxo triazinones, Triazinoindoles, Schiff base, N-Mannich base.

\section{INTRODUCTION}

Heterocyclic skeletons serve as ideal scaffolds on which pharmacophores can be appended to yield potent and selective drugs. ${ }^{1}$. In the family of heterocyclic compounds nitrogen-containing heterocycles are an important class of compounds in the medicinal chemistry and also contribute to the society from biological and industrial point, which helps to understand life processes ${ }^{2}$.

Among nitrogen containing heterocycles, indole represents a pharmaceutically important class of compounds because of its diverse biological activities like antibacterial, antifungal, antiplasmodial and anti $\mathrm{HIV}^{3}$ Further triazine derivatives have also received considerable attention due to their potent bioactivity such as antiprotozoal, anticancer, estrogen receptor modulators, antiviral and antimalarials ${ }^{4}$. Fused triazines are important as basic framework for a variety of pharmaceuticals and agrochemicals ${ }^{5}$. On the basis of immense pharmacological action of indole and triazines, it is noteworthy to synthesize these leads by clubbing together and screening them for biological activities.

For the synthesis of thioxotriazines and indolotriazines, number of reports ${ }^{6}$ have appeared which require drastic conditions, long reaction times, and complex synthetic pathways and often react in organic solvents, which are least desirable commercially. So the ultimate goal of ours is to develop efficient, selective and ecofriendly methods for the synthesis of biodynamic heterocycles. Also because of environmental concerns, it has recently become of significant interest to carry out reactions using environmentally benign techniques.

The application of microwaves ${ }^{7}$ as a non-conventional energy source for activation of reactions has now become a very popular and useful technology in organic chemistry. In this regard the use of water ${ }^{8}$ as a reaction solvent has also attracted great attention in the recent past and has become an active area of research in green chemistry. The combination of microwave irradiation and aqueous mediated conditions lead to enhanced reaction rates, higher yields of pure products, easier workup and sometimes to selective conversions with several advantages of the ecofriendly approach in the framework of green chemistry. Consequently this protocol should be welcomed in these environmentally conscious days.

To the best of knowledge, one pot tandem synthesis of substituted thioxo[1,2,4]triazin-5(2H)-ones and $[1,2,4]$ triazino[5,6-b]indoles in aqueous medium has not been studied so far. Considering the abovementioned reports, and in continuation with the long lasting interest in this area $^{9}$ and particular interest on the use of aqueous medium ${ }^{10}$ for heterocyclic synthesis, we report herein for the first time aqua mediated facile synthesis of novel thioxo[1,2,4] triazin-5(2H)-ones and $[1,2,4]$ triazino $[5,6-b]$ indoles under microwave irradiation (Scheme-1). Variously substituted hydrazinecarbothioamides generated "insitu" by the reaction of hexahydro-1H-indole-2,3-dione and thiosemicarbazide were allowed to react with $\mathrm{NaOH}$ and $\mathrm{K}_{2} \mathrm{CO}_{3}$ affording the desired products thioxotriazines (4) and indolotriazines (6) respectively. The reaction is generally carried out in the presence of large amount of base, which is harmful, toxic and polluting. Further, use of $\mathrm{K}_{2} \mathrm{CO}_{3}$ in presence of microwave irradiation makes the process ecofriendly and economic and makes a new path in green chemical transformation

Insight into the structure activity relationship of hexahydro-1H-indole2,3-dione reveals that N-Mannich bases and Schiff bases of 5-substituted-1Hindole-2,3-dione are reported to have a profound increase in their biological activities ${ }^{11}$. Hence, it was thought worthwhile to explore the use of microwave irradiation for the synthesis of some novel potent bioactive N-Mannich and Schiff bases of $1 \mathrm{H}$-indole-2,3-dione. In view of the above observations and immense utility of the green synthetic approach, we have also carried out the improved synthesis of key intermediate Schiff base (3) and N-Mannich base of hexahydro-1H-indole-2,3-dione (5) in aqueous medium for the first time under microwave irradiation (Scheme-1).

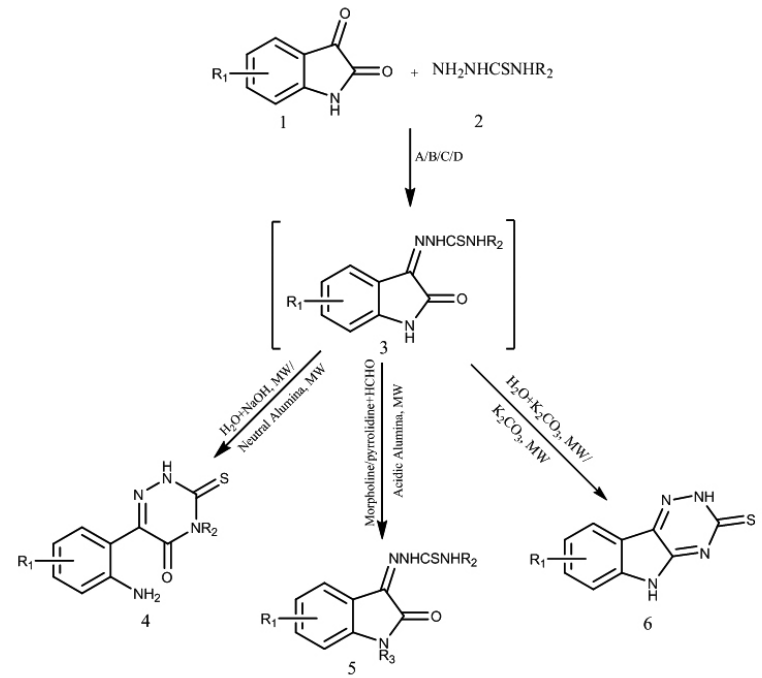

$\mathrm{R}_{1}=\mathrm{H}, 5-\mathrm{Cl}, 5-\mathrm{Br}$

$\mathrm{R}_{2}=\mathrm{H}, 4-\mathrm{ClC}_{6} \mathrm{H}_{4}, 4-\mathrm{BrC}_{6} \mathrm{H}_{4}, 4-\mathrm{CH}_{3} \mathrm{C}_{6} \mathrm{H}_{4}$ $\mathrm{R}_{2}=\mathrm{H}, 4-\mathrm{ClC}_{6} \mathrm{H}_{4}, 4-\mathrm{BrC}_{6} \mathrm{H}_{4}, 4-\mathrm{CH}_{3} \mathrm{C}_{6} \mathrm{H}_{4}$
$\mathrm{R}_{3}=\mathrm{H}$, Morpholinomethyl, pyrrolidinomethy

$A=$ Montmorillonite $\mathrm{K} 10$ clay under microwave $\mathrm{B}=$ Water containing catalytic amount of acetic acid under $\mathrm{B}=$ Water co microwaves
$\mathrm{C}=$ Water containing catalytic amount of montmorillonite $\mathrm{K} 10$ clay
under microwaves $\mathrm{D}=$ Ethanol containing catalytic amount of acetic acid, Reflux 


\section{RESULTS AND DISCUSSION}

The biologically important scaffold 2-(5-substituted-2-oxoindolin-3ylidene)-N-(4-substitutedphenyl) hydrazinecarbothioamides 3(Schiff bases) were prepared by the improved procedure in water by the reaction of substituted hexahydro-1H-indole-2,3-diones (1) and substituted thiosemicarbazide (2) under microwave irradiation (TABLE I). Compound (3) was formed in reasonable purity (TLC) and could be used as such for next step without further purification. Comparative results of the synthesis of $\mathbf{3}$ under different reaction conditions are given in TABLE II.

As the starting point of our exploration, we choose the reaction of hexahydro$1 \mathrm{H}$-indole-2,3-diones and thiosemicarbazide and it has been found that when a equimolar mixture of $\mathbf{1}$ and $\mathbf{2}$ in water was irradiated inside microwave oven for 3-6 minutes, $\mathbf{3}$ was exclusively formed which "insitu" was reacted with $\mathrm{NaOH}$ and $\mathrm{K}_{2} \mathrm{CO}_{3}$ to afford 6-(2-aminophenyl)-4-(4-substituted phenyl)-3thioxo-3,4-dihydro-1,2,4-triazin-5(2H)-one (4) and 3,5dihydro-2H-[1,2,4] triazino[5,6-b]indole (6) respectively. In order to extend our protocol and to explore the scope and limitations of this reaction, further other substituted- $1 \mathrm{H}-$ indole-2,3-diones and thiosemicarbazide bearing electron withdrawing and donating groups, were used successfully to give the corresponding $\mathbf{4 / 6}$ in good to excellent yields $(75-90 \%)$. Using one pot procedure we have synthesized a series of thioxotriazines (4) and indolotriazines (6) under microwave irradiation in aqueous medium. A comparison of time required for the reaction reported clearly indicates tremendous reduction in the time of reaction carried out in the microwave oven along with enhanced yields. (TABLE-III).

Table I: Comparative results of synthesis of 3a-1 under microwave irradiation and conventional heating.

\begin{tabular}{|c|c|c|c|c|c|}
\hline \multirow{2}{*}{ Entry } & \multirow{2}{*}{$\mathrm{R}_{1}$} & \multirow{2}{*}{$\mathrm{R}_{2}$} & \multicolumn{2}{|c|}{ Time/Yield (\%) } & \multirow{2}{*}{ M.p. $\left({ }^{\circ} \mathrm{C}\right)$} \\
\hline & & & MW & Conventional & \\
\hline $3 a$ & $\mathrm{H}$ & $\mathrm{H}$ & $3 \min . / 84$ & $6 \mathrm{~h} / 54$ & $240^{12}$ \\
\hline $3 b$ & $5-\mathrm{Cl}$ & $\mathrm{H}$ & $4 \mathrm{~min} . / 86$ & $6 \mathrm{~h} / 55$ & 262 \\
\hline $3 \mathrm{c}$ & $5-\mathrm{Br}$ & $\mathrm{H}$ & $4 \mathrm{~min} . / 77$ & $7 \mathrm{~h} / 53$ & 266 \\
\hline $3 d$ & $\mathrm{H}$ & $4-\mathrm{Cl} \mathrm{C}_{6} \mathrm{H}_{4}$ & $4 \mathrm{~min} . / 76$ & $6 \mathrm{~h} / 53$ & 280 \\
\hline $3 \mathrm{e}$ & $5-\mathrm{Cl}$ & 4- $\mathrm{Cl} \mathrm{C}{ }_{6}^{6} \mathrm{H}_{4}^{4}$ & $4 \mathrm{~min} . / 86$ & $7 \mathrm{~h} / 54$ & 275 \\
\hline $3 f$ & $5-\mathrm{Br}$ & 4- $\mathrm{Cl} \mathrm{C}{ }_{6}^{6} \mathrm{H}_{4}^{4}$ & $6 \mathrm{~min} . / 81$ & $7 \mathrm{~h} / 55$ & 170 \\
\hline $3 \mathrm{~g}$ & $\mathrm{H}$ & 4- $\mathrm{Br} \mathrm{C}_{6} \mathrm{H}_{4}^{4}$ & $4 \mathrm{~min} . / 78$ & $6 \mathrm{~h} / 50$ & 215 \\
\hline $3 \mathrm{~h}$ & $5-\mathrm{Cl}$ & 4- $\mathrm{Br} \mathrm{C}_{6}^{6} \mathrm{H}_{4}^{4}$ & $6 \mathrm{~min} . / 74$ & $7 \mathrm{~h} / 57$ & 220 \\
\hline $3 \mathrm{i}$ & $5-\mathrm{Br}$ & 4- $\mathrm{Br} \mathrm{C}_{6}^{\circ} \mathrm{H}_{4}^{4}$ & $4 \mathrm{~min} . / 88$ & $7 \mathrm{~h} / 52$ & 224 \\
\hline $3 \mathrm{j}$ & $\mathrm{H}$ & $4-\mathrm{CH}_{2} \mathrm{CH}_{4}^{4}$ & $4 \mathrm{~min} . / 88$ & $6 \mathrm{~h} / 54$ & 270 \\
\hline $3 \mathrm{k}$ & $5-\mathrm{Cl}$ & $4-\mathrm{CH}_{3}^{3} \mathrm{C}_{6}^{6} \mathrm{H}_{4}^{4}$ & $6 \mathrm{~min} . / 88$ & $7 \mathrm{~h} / 55$ & 235 \\
\hline 31 & $5-\mathrm{Br}$ & $4-\mathrm{CH}_{3}^{3} \mathrm{C}_{6}^{6} \mathrm{H}_{4}^{4}$ & $6 \mathrm{~min} . / 86$ & $7 \mathrm{~h} / 54$ & 200 \\
\hline
\end{tabular}

Table II: Comparative study for synthesis of 2-(2-oxoindolin-3-ylidene)hydrazinecarbothioamide (3a) under different reaction conditions.

\begin{tabular}{|c|c|c|c|c|}
\hline Entry & Reaction Conditions & Method & Time (min./h) & Yield (\%) \\
\hline & Ethanol/Methanol & Conventional & $5 \mathrm{~h}$ & 54 \\
i & Montmorillonite K10 & MW & $5 \mathrm{~min}$. & 80 \\
ii & Water containing acetic acid & MW & $4 \mathrm{~min}$. & 82 \\
iii & Water containing montmorillonite & MW & $3 \mathrm{~min}$. & 84 \\
iv & K10 clay & & \\
\hline
\end{tabular}

The $[1,2,4]$ triazin-5(2H)-ones (4)/triazino[5,6-b]indoles (6) has been synthesized earlier ${ }^{6}$ conventionally by a two step procedure in $35-60 \%$ yield using hydrazinecarbothioamides (3) as key intermediate. The classical methods use large amount of base at elevated temperature for several hours of heating and the products are generally purified by crystallization with further need of solvent. In this context suitability of different solid supports was also examined that included acidic, basic or neutral alumina, silica gel, $\mathrm{K}_{2} \mathrm{CO}_{3}$ montmorillonite $\mathrm{KSF}$ and $\mathrm{K} 10$ to check the most effective condition for the synthesis of target compounds $\mathbf{4 / 6}$. Initially, we examined the reaction of (3) in ethanol with $\mathrm{NaOH} / \mathrm{K} \mathrm{CO}$ under conventional method and observed that desired product $\mathbf{4 / 6}$ was formed in low yield. Further, all our attempts to improve the yield at elevated temperatures and longer reaction times were met with unsuccessful results. To increase the efficiency, we decided to perform the reaction of (3) with $\mathrm{NaOH} / \mathrm{K} \mathrm{CO}$ "insitu" under mild condition in water using microwaves and observed that the reaction proceeded uneventfully forming the desired product $\mathbf{4} / \mathbf{6}$ respectively in good to excellent yields. (TABLE III)

Table III: Comparative results of one pot synthesis of 4a-h and 6a-c under microwave irradiation and conventional heating.

\begin{tabular}{|c|c|c|c|c|c|c|}
\hline \multirow{3}{*}{ Entry } & \multirow{3}{*}{$\mathrm{R}_{1}$} & \multirow{3}{*}{$\mathrm{R}_{2}$} & \multicolumn{3}{|c|}{ Time/Yield (\%) } & \multirow{3}{*}{ M.p. $\left({ }^{\circ} \mathrm{C}\right)$} \\
\hline & & & \multicolumn{2}{|c|}{ MW } & Conventional & \\
\hline & & & \multicolumn{2}{|c|}{ Method A } & Method B & \\
\hline $4 a$ & $\mathrm{H}$ & $\mathrm{H}$ & $6 \mathrm{~min} . / 82$ & $6 \mathrm{~min} . / 80$ & $4 \mathrm{~h} / 48$ & 265 \\
\hline $4 b$ & $\mathrm{H}$ & $\mathrm{C}_{6} \mathrm{H}_{4} \mathrm{Cl}$ & $8 \mathrm{~min} . / 87$ & $8 \mathrm{~min} . / 73$ & $5 \mathrm{~h} / 52$ & 280 \\
\hline $4 c$ & $\mathrm{H}$ & $\mathrm{C}_{6}^{6} \mathrm{H}_{4}^{4} \mathrm{Br}$ & $8 \mathrm{~min} . / 76$ & $8 \mathrm{~min} . / 78$ & $5 \mathrm{~h} / 45$ & 285 \\
\hline $4 \mathrm{f}$ & $5-\mathrm{Cl}$ & $\mathrm{C}_{6}^{0} \mathrm{H}_{4}^{4} \mathrm{Br}$ & $8 \mathrm{~min} . / 77$ & 8 min. $/ 75$ & $7 \mathrm{~h} / 42$ & 290 \\
\hline $4 \mathrm{~g}$ & $5-\mathrm{Br}$ & ${ }^{6}{ }^{4}$ & $9 \mathrm{~min} . / 82$ & $8 \mathrm{~min} . / 86$ & $6 \mathrm{~h} / 62$ & 285 \\
\hline $4 \mathrm{~h}$ & $5-\mathrm{Br}$ & $\mathrm{C}_{6} \mathrm{H}_{4} \mathrm{Cl}$ & $7 \mathrm{~min} . / 75$ & $8 \mathrm{~min} . / 72$ & $6 \mathrm{~h} / 43$ & 331 \\
\hline $6 \mathrm{a}$ & $\mathrm{H}$ & $\mathrm{H}^{4}$ & $10 \mathrm{~min} . / 86$ & $12 \mathrm{~min} / 81$ & $7 \mathrm{~h} / 64$ & 340 \\
\hline $6 \mathrm{~b}$ & $5-\mathrm{Cl}$ & $\mathrm{H}$ & $12 \mathrm{~min} . / 87$ & $14 \mathrm{~min} . / 74$ & $7 \mathrm{~h} / 57$ & 355 \\
\hline $6 \mathrm{c}$ & $5-\mathrm{Br}$ & $\mathrm{H}$ & $12 \mathrm{~min} . / 82$ & $12 \mathrm{~min} . / 72$ & $7 \mathrm{~h} / 52$ & 348 \\
\hline
\end{tabular}


From the results of TABLE III, it can be concluded that very good result was obtained in aqueous medium under microwaves giving the pure crystalline product upon post reaction cooling, comparatively high yield was achieved in few minutes and consequently we extended same conditions to synthesize a new series of 1,2,4-triazin-5(2H)-ones (4)/triazino[5,6-b]indoles (6) under microwave irradiation. We have also carried out the synthesis of $\mathbf{6}$ by adsorbing 3 on potassium carbonate surface without using any strong base. Potassium carbonate is a mild base, inexpensive and water-soluble which further eliminates the use of organic solvents required (TABLE III).

Improved synthesis of N-Mannich base of 1H-indole-2,3-dione (5) was also carried out by the reaction of (3) with formaldehyde and morpholine/pyrrolidine using acidic alumina as inorganic solid support under microwave irradiation. Reaction was faster giving enhanced yields (90-95\%), cleaner reaction products and easier work up as compared to standard thermal conditions (65-75\% yield)(TABLE IV).

Table IV: Comparative results of synthesis of (5a-f) under microwave irradiation and conventional heating.

\begin{tabular}{|c|c|c|c|c|c|c|}
\hline \multirow{2}{*}{ Entry } & \multirow{2}{*}{$\mathrm{R}_{1}$} & \multirow{2}{*}{$\mathrm{R}_{2}$} & \multirow{2}{*}{$\mathrm{R}_{3}$} & \multicolumn{2}{|c|}{ Time/Yield (\%) } & \multirow{2}{*}{ M.pt. $\quad\left({ }^{\circ} \mathrm{C}\right)$} \\
\hline & & & & MW & Conventional & \\
\hline $5 \mathrm{a}$ & $\mathrm{H}$ & $\mathrm{H}$ & $-\mathrm{CH}_{2}-\mathrm{I}$ & $6 \mathrm{~min} . / 95$ & $8 \mathrm{~h} / 70$ & 195 \\
\hline $5 b$ & $\mathrm{H}$ & $\mathrm{C}_{6} \mathrm{H}_{4} \mathrm{Cl}$ & $-\mathrm{CH}_{2}$ & $7 \mathrm{~min} . / 93$ & $8 \mathrm{~h} / 68$ & 210 \\
\hline $5 c$ & $\mathrm{H}$ & $\mathrm{C}_{6} \mathrm{H}_{4} \mathrm{Br}$ & $-\mathrm{CH}_{2}$ & $7 \mathrm{~min} . / 97$ & $9 \mathrm{~h} / 65$ & 230 \\
\hline $5 \mathrm{~d}$ & $5-\mathrm{Cl}$ & $\mathrm{C}_{6} \mathrm{H}_{4} \mathrm{Cl}$ & $-\mathrm{CH}_{2}$ & $8 \min . / 87$ & $8 \mathrm{~h} / 70$ & 178 \\
\hline $5 \mathrm{e}$ & $5-\mathrm{Cl}$ & $\mathrm{C}_{6} \mathrm{H}_{4} \mathrm{Br}$ & $-\mathrm{CH}_{2}$ & $7 \mathrm{~min} . / 91$ & $9 \mathrm{~h} / 63$ & 162 \\
\hline $5 \mathrm{f}$ & $5-\mathrm{Cl}$ & $\mathrm{H}$ & $-\mathrm{CH}_{2}$ & $7 \mathrm{~min} . / 95$ & $8 \mathrm{~h} / 73$ & 140 \\
\hline
\end{tabular}

\section{CONCLUSION}

We have developed environmentally benign and expeditious microwave method for the efficient, clean and quick synthesis of biologically important new 6-(2-aminophenyl)-4-(4-substituted phenyl)-3-thioxo-3,4-dihydro-1,2,4triazin-5 $(2 H)$-one and 8-substituted 3,5-dihydro- $2 H$-[1,2,4]triazino[5,6-b] indole derivatives in aqueous medium with greater yields than the previously reported conventional methods. The use of water gives environmental benefits i.e. no atmospheric pollution by escaping solvents easy waste treatment. For this reason this methodology represents an important improvement for the production of this kind of fine chemicals following environmentally benign procedures.

\section{EXPERIMENTAL}

Reagents and solvents were obtained from commercial sources and used without further purification. Melting points were determined on a Toshniwal apparatus. The elemental and spectral analyses of synthesized compounds have been carried out at SAIF Punjab University, Chandigarh. The purity of compounds was checked on thin layers of silica gel in various non-aqueous solvent systems, e.g. benzene: ethylacetate $(9: 1)$, benzene: ethylacetate $(8: 2)$, benzene: Petroleum ether $(8: 2)$, benzene: dichloromethane $(8: 2)$, n-hexane: ethyl acetate (7:3), hexane: ethyl acetate (8:2), benzene: ethylacetate:methanol (7:2:1). IR spectra were recorded in $\mathrm{KBr}$ on a Perkin Elmer Infrared RXI FTIR spectrophotometer and 1H NMR spectra were recorded on Bruker Avance II 400 NMR Spectrometer using DMSO-d and $\mathrm{CDCl}_{3}$ as solvent and tetramethylsilane (TMS) as internal reference standard. The microwaveassisted reactions were carried out in a commercial multimode microwave oven operating at $1000 \mathrm{~W}$ generating $2450 \mathrm{MHz}$ frequency.

Synthesis of 2-(5-substituted-2-oxoindolin-3-ylidene)-N-(4substitutedphenyl)hydrazine carbothioamides (3a).

Conventional method. Compound 3a was synthesized following the literature ${ }^{12}$ method. M.p. $240{ }^{\circ} \mathrm{C}$, Yield $54 \%$.

Microwave irradiation method. Compound 3a was synthesized by three different methods under microwave irradiation Method A. An equimolar $(1 \mathrm{mmol})$ mixture of 1a and 2a was adsorbed on montmorillonite K10 clay ( $20 \%$ by weight of the reactants) via a solution in acetone, mixed thoroughly and irradiated inside microwave oven for $5 \mathrm{~min}$. at 600 watts while monitoring the course of the reaction by TLC. The compound was extracted with dichloromethane. The excess solvent was evaporated on rota-evaporator and the solid obtained was recrystallized from ethanol to afford the product $3 \mathrm{a}$.

M.p. $240{ }^{\circ} \mathrm{C}$ Yield: $80 \%$

Method B. An equimolar mixture of 1a and 2a in water containing catalytic amount of acetic acid was irradiated inside microwave oven for 4 min. at 200 watts while monitoring the course of the reaction by TLC. Product formed was filtered and recrystallized from ethanol. M.p. $240{ }^{\circ} \mathrm{C}$ Yield: $82 \%$.

Method C. An equimolar mixture of $\mathbf{1 a}$ and $\mathbf{2 a}$ in water containing catalytic amount of clay was irradiated inside microwave oven for $3 \mathrm{~min}$. at 200 watts (as monitored by TLC). Product formed was filtered and recrystallized from ethanol. M.p. $240{ }^{\circ} \mathrm{C}$ Yield: $84 \%$.

The compounds $\mathbf{3 b}$-I were prepared by following Method C (Table-I) and structure of the compounds was confirmed by spectral studies. Comparative 
results of the synthesis of $3 \mathrm{a}$ under different reaction conditions are given in TABLE II.

General procedure for the synthesis of 6-(2-aminophenyl)-4-(4substitutedphenyl)-3-thioxo-3,4-dihydro-1,2,4-triazin-5(2H)-one (4)

Conventional Method. 3 (2.0gm) was dissolved in a boiling solution of $\mathrm{NaOH}(1 \mathrm{M}, 100 \mathrm{ml})$ in $250 \mathrm{ml}$ conical flask. This mixture was refluxed for 6-7 hrs. After cooling, the mixture was acidified with acetic acid. The solid formed was immediately filtered off, washed with water and dried affording product 4 .

Microwave irradiation method. Compound 4 was synthesized by two different methods under microwave irradiation (Table-III).

Method A. An equimolar ( $1 \mathrm{mmol})$ mixture of $\mathbf{1}$ and $\mathbf{2}$ in water was irradiated inside microwave oven at 200 watts power output until the completion of reaction (TLC control). As the reactants disappeared, $10 \mathrm{mmol}$ of $\mathrm{NaOH}$ was added and again irradiated for appropriate time under microwave irradiation. The crystalline product started to separate out just after cooling the reaction mixture, which was washed with water and found to be pure by TLC, with no need of further purification process. All compounds were synthesized similarly in comparatively high yields and reduced times using water under microwave irradiation. For analytical and spectral data, compounds were recrystallized from ethanol+DMF (1:1) ratio.

Method B. A mixture of 3 and $\mathrm{NaOH}$ adsorbed on neutral alumina $(20 \%$ by weight of the reactants) with the help of ethanol, mixed thoroughly and irradiated under microwaves for 6-10 minutes at 400 watts. Product obtained was separated by filtration after eluting the reaction mixture with ethanol. The excess solvent was evaporated on rota-evaporator to give crystals of $\mathbf{4}$, which were found to be pure with no need of further purification.

General procedure for the synthesis of 2-(1-(morpholinomethyl/ pyrrolidin-1-ylmethyl)-2-oxoindolin-3-ylidene) hydrazine carbothioamide (5)

Conventional method. To a suspension of $\mathbf{3}(2 \mathrm{mmol})$ in absolute ethanol $(20 \mathrm{ml}), 37 \%$ formaldehyde solution $(0.5 \mathrm{ml})$ and morpholine/pyrrolidine ( $2 \mathrm{mmol})$ were added dropwise with vigorous stirring. After combining all the reagents, the reaction mixture was stirred with gentle refluxing for $8-9 \mathrm{hrs}$. The solid product was collected by filtration and washed with petroleum ether to obtain pure product.

Microwave irradiation method. A mixture of 3, 37\% $\mathrm{HCHO}(0.5 \mathrm{ml})$ and morpholine/pyrrolidine ( $2 \mathrm{mmole})$ was adsorbed on acidic alumina $(20 \%$ by weight of reactants) via ethanol, mixed thoroughly and irradiated inside microwave oven for 5- 6 minutes at 300watts while monitoring the course of the reaction by TLC. The product was extracted with dichloromethane. The excess solvent was evaporated on rota-evaporator to give crystals of $\mathbf{5}$, which were found to be pure on TLC.

General procedure for the synthesis of 8-substituted 3,5-dihydro$2 H$-[1,2,4] triazino $[5,6-b]$ indole $(6)$

Conventional Method. A mixture of $3(0.01 \mathrm{~mol})$ and anhydrous $\mathrm{K}_{2} \mathrm{CO}_{3}$ $(10 \mathrm{gm})$ in absolute ethanol was refluxed for 7-8 hrs. After the completion of reaction (as monitored by TLC), reaction mixture was cooled and then poured on to crushed ice containing catalytic amount of acetic acid. The obtained solid was filtered off, dried and recrystallized from ethanol.

Microwave irradiation method. Compound $\mathbf{6}$ was synthesized by two different methods under microwave irradiation (Table-III). Method A. An equimolar $(1 \mathrm{mmol})$ mixture of $\mathbf{1}$ and $\mathbf{2}$ in water was irradiated inside microwave oven at 200 watts power output until the completion of reaction (TLC control). As the reactants disappeared, $\mathrm{K}_{2} \mathrm{CO}_{3}(0.04 \mathrm{~mol})$ was added and again irradiated for appropriate time under microwave irradiation. The crystalline product started to separate out just after cooling the reaction mixture, which was washed with water and found to be pure by TLC, with no need of further purification process. All compounds were synthesized similarly in comparatively high yields and reduced times using water under microwaves. For analytical and spectral data, compounds were recrystallized from ethanol. Method B. 3 was adsorbed on activated potassium carbonate surface with the help of methanol and irradiated inside microwave oven for $12-14 \mathrm{~min}$. at 400 watts power output. After the completion of the reaction, the reaction mixture was cooled and the product was extracted with ethanol. The excess solvent was evaporated on rota- evaporator to give crystals of $\mathbf{6}$, which were found to be pure on TLC.

Compound 3a IR $\left(\mathrm{KBr}, \mathrm{cm}^{-1}\right)$ : 3428(N-H stretching of indole), 3234(N$\mathrm{H}$ stretching of hydrazinecarbothioamide), $1698(\mathrm{C}=\mathrm{O}$ str), $1153(\mathrm{C}=\mathrm{S}$ str); ${ }^{1} \mathrm{HNMR}\left(400 \mathrm{MHz}, \mathrm{DMSO}-\mathrm{d}_{6}\right): \delta 6.90\left(\mathrm{~d}, 1 \mathrm{H}, \mathrm{C} 4 \mathrm{H}\right.$ proton), 7.04(t, $1 \mathrm{H} \mathrm{C}_{5} \mathrm{H}$ proton), 7.32(t, $1 \mathrm{H} \mathrm{C} \mathrm{H}$ proton), 7.78 (d, $1 \mathrm{H} \mathrm{C} \mathrm{C}_{7} \mathrm{H}$ of indole), $8.36\left(\mathrm{~s}, 2 \mathrm{H}, \mathrm{NH}_{2}\right.$ of hydrazinecarbothioamide moiety), $11.12(\mathrm{~S}, 1 \mathrm{H}, \mathrm{NH}$ of indole), 11.15(s, $1 \mathrm{H}, \mathrm{NH}$ of hydrazinecarbothioamide moiety) ppm; Anal. Calcd for $\mathrm{C}_{9} \mathrm{H}_{8} \mathrm{~N}_{4} \mathrm{OS}$ : C, 49.34; H, 3.63; N, 25.17\%. Found: C, 49.20; H, 3.61; N, $25.20 \%$.; MS: $[\mathrm{M}]^{+}$at $\mathrm{m} / \mathrm{z} 220$.

Compound 3b IR $\left(\mathrm{KBr}, \mathrm{cm}^{-1}\right)$ : 3425(N-H stretching of indole), 3235( $\mathrm{N}-\mathrm{H}$ stretching of hydrazinecarbothioamide moiety), $1697(\mathrm{C}=\mathrm{O}$ str), $1152\left(\mathrm{C}=\mathrm{S}\right.$ str); ${ }^{1} \mathrm{HNMR}\left(400 \mathrm{MHz}, \mathrm{DMSO}-\mathrm{d}_{6}\right): \delta 6.86\left(\mathrm{~d}, 1 \mathrm{H}, \mathrm{C}_{4} \mathrm{H}\right.$ proton), 7.26(d, $1 \mathrm{H} \mathrm{C}_{6} \mathrm{H}$ proton), 7.87 (d, $1 \mathrm{H} \mathrm{C}_{7} \mathrm{H}$ of indole), 8.36(s, $2 \mathrm{H}, \mathrm{NH}_{2}$ of hydrazinecarbothioamide moiety), $11.12(\mathrm{~s}, 1 \mathrm{H}, \mathrm{NH}$ of indole), $11.15(\mathrm{~s}, 1 \mathrm{H}, \mathrm{NH}$ of hydrazinecarbothioamide moiety) ppm; Anal. Calcd for $\mathrm{C}_{9} \mathrm{H}_{7} \mathrm{~N}$ OSCl: $\mathrm{C}$, 42.43; H, 2.75; N, 22.00 Found: C, 42.18; H, 2.71; N, $22.03 \%$; MS: [M] $]^{+}$at $\mathrm{m} / \mathrm{z} 254.5$.

Compound 3c IR $\left(\mathrm{KBr}, \mathrm{cm}^{-1}\right)$ 3424(N-H stretching of indole), 3236( $\mathrm{N}-\mathrm{H}$ stretching of hydrazinecarbothioamide moiety), $1698(\mathrm{C}=\mathrm{O}$ str $)$, $1154\left(\mathrm{C}=\mathrm{S}\right.$ str); ${ }^{1} \mathrm{HNMR}\left(400 \mathrm{MHz}, \mathrm{DMSO}-\mathrm{d}_{6}\right): \delta 6.84(\mathrm{~d}, 1 \mathrm{H}, \mathrm{C} 4 \mathrm{H}$ proton $)$, 7.25(d, 1 $\mathrm{H} \mathrm{C} \mathrm{H}$ proton), $7.83\left(\mathrm{~d}, 1 \mathrm{H} \mathrm{C}_{7} \mathrm{H}\right.$ of indole), $8.37\left(\mathrm{~s}, 2 \mathrm{H}, \mathrm{NH}_{2}\right.$ of hydrazinecarbothioamide moiety), $11.12(\mathrm{~s}, 1 \mathrm{H}, \mathrm{NH}$ of indole), $11.15(\mathrm{~s}, 1 \mathrm{H}, \mathrm{NH}$ of hydrazinecarbothioamide moiety) ppm;Anal. Calcd for $\mathrm{C}_{9} \mathrm{H}_{7} \mathrm{~N}_{4} \mathrm{OSBr}$ : C, 36.12; H, 2.34;N, 18.72\%. Found: C, 36.00; H, 2.31; N, $18.75 \%$; MS: [M] $]^{+}$ at $\mathrm{m} / \mathrm{z} 299$.

Compound 3d IR $\left(\mathrm{KBr}, \mathrm{cm}^{-1}\right)$ : 3439(N-H stretching of indole), 3235(N$\mathrm{H}$ stretching of hydrazinecarbothioamide moiety), 1699(C=Ostr), 1154(C=S str); ${ }^{1} \mathrm{HNMR}\left(400 \mathrm{MHz}, \mathrm{DMSO}-\mathrm{d}_{6}: \delta 6.91\left(\mathrm{~d}, 1 \mathrm{H}, \mathrm{C} 4 \mathrm{H}\right.\right.$ proton), $7.08\left(\mathrm{t}, 1 \mathrm{H} \mathrm{C}_{5} \mathrm{H}\right.$ proton), 7.33(d, $1 \mathrm{H} \mathrm{C}_{6} \mathrm{H}$ proton), 7.85 (d, $1 \mathrm{H} \mathrm{C}_{7} \mathrm{H}$ of indole), 7.22-7.90 $(\mathrm{m}, 4 \mathrm{H}$, Ar-H), 12.28 (br, 1H, -NH-Ar), 11.12 (s, 1H, NH of indole), 11.14 (s, 1H,NH of hydrazinecarbothioamide moiety) ppm; Anal Calcd for $\mathrm{C}_{15} \mathrm{H}_{11} \mathrm{~N}_{4} \mathrm{OSCl}$ : C, 54.46; H, 3.32; N, 16.94.Found: C, 54.60; H, 3.34; N, 16.91\%; MS: [M] ${ }^{+}$at $\mathrm{m} / \mathrm{z} 330.5$

Compound 3e IR $\left(\mathrm{KBr}, \mathrm{cm}^{-1}\right)$ : 3432(N-H stretching of indole), 3237(N$\mathrm{H}$ stretching of hydrazinecarbothioamide moiety $), 1700(\mathrm{C}=\mathrm{O}$ str $), 1156(\mathrm{C}=\mathrm{S}$ str); ${ }^{1} \mathrm{HNMR}\left(400 \mathrm{MHz}, \mathrm{DMSO}-\mathrm{d}_{6}\right): \quad \delta 6.88(\mathbf{d}, 1 \mathrm{H}, \mathrm{C} 4 \mathrm{H}$ proton), $7.30(\mathrm{~d}$, $1 \mathrm{H} \mathrm{C}_{6} \mathrm{H}$ proton), $7.89\left(\mathrm{~d}, 1 \mathrm{H} \mathrm{C}_{7} \mathrm{H}\right.$ of indole), 7.22-7.90 (m, 4H, Ar-H), $12.30(\mathrm{br}, 1 \mathrm{H},-\mathrm{NH}-\mathrm{Ar}), 11.12(\mathrm{~s}, 1 \mathrm{H}, \mathrm{NH}$ of indole), $11.15(\mathrm{~s}, 1 \mathrm{H}, \mathrm{NH}$ of hydrazinecarbothioamide moiety), ppm; Anal. Calcd for $\mathrm{C}_{15} \mathrm{H}_{10} \mathrm{~N}_{4} \mathrm{OSCl}_{2}$ : C, 55.33; H, 3.15; N, 13.59 Found: C, 55.10; H, 3.11; N, 13.55\%; MS: [M] $]^{+}$at $\mathrm{m} / \mathrm{z} 365.5$.

Compound 3f IR ( $\left.\mathrm{KBr}, \mathrm{cm}^{-1}\right)$ : 3432(N-H stretching of indole), 3237(N$\mathrm{H}$ stretching of hydrazinecarbothioamide moiety $), 1700(\mathrm{C}=\mathrm{O}$ str $), 1156(\mathrm{C}=\mathrm{S}$ str); ${ }^{1} \mathrm{HNMR}\left(400 \mathrm{MHz}, \mathrm{DMSO}-\mathrm{d}_{6}\right): \delta 6.92\left(\mathrm{~d}, 1 \mathrm{H}, \mathrm{C}_{4} \mathrm{H}\right.$ proton $), 7.51(\mathrm{~d}$, $1 \mathrm{H} \mathrm{C} \mathrm{H}$ proton), $7.78\left(\mathrm{~d}, 1 \mathrm{H} \mathrm{C} \mathrm{C}_{7} \mathrm{H}\right.$ of indole $), 7.22-7.90(\mathrm{~m}, 4 \mathrm{H}, \mathrm{Ar}-\mathrm{H})$, 12.30 (br, 1H, -NH-Ar), 11.12 (s, 1H, NH of indole), 11.18 (s, 1H,NH of hydrazinecarbothioamide moiety) ppm; Anal. Calcd for $\mathrm{C}_{15} \mathrm{H}_{10} \mathrm{~N}_{4} \mathrm{OSClBr}$ : C, 43.95; H, 2.44; N, 13.67 Found: C, 43.80; H, 2.40; N, $13.62 \%$; MS: [M] ${ }^{+}$at $\mathrm{m} / \mathrm{z} 409.5$.

Compound 3g IR $\left(\mathrm{KBr}, \mathrm{cm}^{-1}\right)$ : 3432(N-H stretching of indole), 3237(N$\mathrm{H}$ stretching of hydrazinecarbothioamide moiety $), 1700(\mathrm{C}=\mathrm{O}$ str $), 1156(\mathrm{C}=\mathrm{S}$ str); ${ }^{1} \mathrm{HNMR}\left(400 \mathrm{MHz}\right.$, DMSO-d $\left.\mathrm{d}_{6}\right): \delta 6.91\left(\mathrm{~d}, 1 \mathrm{H}, \mathrm{C}_{4} \mathrm{H}\right.$ proton), $7.08\left(\mathrm{t}, 1 \mathrm{H} \mathrm{C}_{5} \mathrm{H}\right.$ proton), 7.33(d, $1 \mathrm{H} \mathrm{C} \mathrm{H}$ proton), $7.58\left(\mathrm{~d}, 1 \mathrm{H} \mathrm{C} \mathrm{H}_{7}\right.$ of indole), $7.22-7.90(\mathrm{~m}, 4 \mathrm{H}$, Ar-H), 12.18 (br, 1H, -NH-Ar), 11.12 (s, 1H, NH of indole), 11.18 (s, 1H,NH of hydrazinecarbothioamide moiety) ppm; Anal. Calcd for $\mathrm{C}_{15} \mathrm{H}_{11} \mathrm{~N}_{4} \mathrm{OSBr}$ : C, 48.00; H, 2.93; N, 14.93 Found: C, 48.25; H, 2.90; N, $14.96 \%$; MS: [M] $]^{+}$at $\mathrm{m} / \mathrm{z} 375$.

Compound 3h IR ( $\left.\mathrm{KBr}, \mathrm{cm}^{-1}\right)$ : 3432(N-H stretching of indole), 3237 (N-H stretching of hydrazinecarbothioamide moiety), $1700(\mathrm{C}=\mathrm{O}$ str), $1156\left(\mathrm{C}=\mathrm{S}\right.$ str); ${ }^{1} \mathrm{HNMR}\left(400 \mathrm{MHz}, \mathrm{DMSO}-\mathrm{d}_{6}\right): \quad \delta 6.86(\mathrm{~d}, 1 \mathrm{H}, \mathrm{C} 4 \mathrm{H}$ proton), 7.26(d, $1 \mathrm{H} \mathrm{C} \mathrm{H}$ proton), 7.87 (d, $1 \mathrm{H} \mathrm{C} \mathrm{C}_{7}$ of indole), 7.22-7.90 (m, $4 \mathrm{H}, \mathrm{Ar}-$ $\mathrm{H}), 12.30$ (br, 1H, -NH-Ar), 11.12 (s, 1H, NH of indole), 11.18 (s, 1H,NH of hydrazinecarbothioamide moiety) ppm; Anal. Calcd for $\mathrm{C}_{15} \mathrm{H}_{10} \mathrm{~N}_{4} \mathrm{OSBrCl}$ : C,

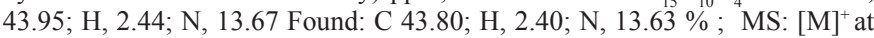
$\mathrm{m} / \mathrm{z} 409.5$. 
Compound 3i IR $\left(\mathrm{KBr}, \mathrm{cm}^{-1}\right)$ : 3432(N-H stretching of indole), 3237(N-H stretching of hydrazinecarbothioamide moiety), $1700(\mathrm{C}=\mathrm{O}$ str), $1156(\mathrm{C}=\mathrm{S}$ str); ${ }^{1} \mathrm{HNMR}\left(400 \mathrm{MHz}\right.$, DMSO- $\left.\mathrm{d}_{6}\right): \delta 6.93\left(\mathrm{~d}, 1 \mathrm{H}, \mathrm{C}_{4} \mathrm{H}\right.$ proton $), \quad 7.53\left(\mathrm{~d}, 1 \mathrm{H} \mathrm{C} \mathrm{C}_{6} \mathrm{H}\right.$ proton), 7.78 (d, 1 $\mathrm{H} \mathrm{C}_{7} \mathrm{H}$ of indole), 7.22-7.90 (m, $\left.4 \mathrm{H}, \mathrm{Ar}-\mathrm{H}\right), 12.20(\mathrm{br}, 1 \mathrm{H},-\mathrm{NH}-$ Ar), $11.12(\mathrm{~s}, 1 \mathrm{H}, \mathrm{NH}$ of indole $), 11.18(\mathrm{~s}, 1 \mathrm{H}, \mathrm{NH}$ of hydrazinecarbothioamide moiety) ppm. Anal. Calcd for $\mathrm{C}_{15} \mathrm{H}_{10} \mathrm{~N}_{4} \mathrm{OSBr}_{2}$ : C, 39.64; H, 2.20; N, 12.33 Found: C, 39.50; H, 2.15; N, $12.30 \%$; MS: [M] ${ }^{+}$at m/z 454 .

Compound 3j IR $\left(\mathrm{KBr}, \mathrm{cm}^{-1}\right)$ : 3432(N-H stretching of indole), 3237(N-H stretching of hydrazinecarbothioamide moiety $), 1700(\mathrm{C}=\mathrm{O}$ str $), 1156(\mathrm{C}=\mathrm{S}$ str $)$; ${ }^{1} \mathrm{HNMR}\left(400 \mathrm{MHz}, \mathrm{DMSO}-\mathrm{d}_{\mathrm{s}}\right): \delta 2.28(\mathrm{~s}, 3 \mathrm{H}, \mathrm{CH} 3), 6.78\left(\mathrm{~d}, 1 \mathrm{H}, \mathrm{C}_{4} \mathrm{H}\right.$ proton), 7.05(t, $1 \mathrm{H} \mathrm{C}_{5} \mathrm{H}$ proton), 7.28(d, $1 \mathrm{H} \mathrm{C}_{6} \mathrm{H}$ proton), $7.66\left(\mathrm{~d}, 1 \mathrm{H} \mathrm{C}_{7} \mathrm{H}\right.$ of indole), 7.54-7.72 (m, 4H, Ar-H), 12.28 (br, $1 \mathrm{H},-\mathrm{NH}-\mathrm{Ar}), 11.12$ (s, $1 \mathrm{H}, \mathrm{NH}$ of indole), 11.15 (s, $1 \mathrm{H}, \mathrm{NH}$ of hydrazinecarbothioamide moiety) ppm; Anal. Calcd for $\mathrm{C}_{16} \mathrm{H}_{14} \mathrm{~N}_{4} \mathrm{OS}$ : C, 61.00; H, 4.50; N, 18.06; Found: C, 61.20; H, 4.55; N, 18.10 $\%$; MS: [M] $]^{+}$at $\mathrm{m} / \mathrm{z} 310$.

Compound 3k IR ( $\left.\mathrm{KBr}, \mathrm{cm}^{-1}\right)$ : 3432(N-H stretching of indole), 3237(N-H stretching of hydrazinecarbothioamide moiety $), 1700(\mathrm{C}=\mathrm{O}$ str $), 1156(\mathrm{C}=\mathrm{S}$ str $)$; ${ }^{1} \mathrm{HNMR}\left(400 \mathrm{MHz}, \mathrm{DMSO}-\mathrm{d}_{6}\right): \delta 2.28$ (s, $\left.3 \mathrm{H}, \mathrm{CH} 3\right), 6.87\left(\mathrm{~d}, 1 \mathrm{H}, \mathrm{C}_{4} \mathrm{H}\right.$ proton), 7.28(d, $1 \mathrm{H} \mathrm{C}_{6} \mathrm{H}$ proton $), 7.86\left(\mathrm{~d}, 1 \mathrm{H} \mathrm{C} \mathrm{C}_{7} \mathrm{H}\right.$ of indole $), 7.54-7.72(\mathrm{~m}, 4 \mathrm{H}, \mathrm{Ar}-$ $\mathrm{H}), 12.28(\mathrm{br}, 1 \mathrm{H},-\mathrm{NH}-\mathrm{Ar}), 11.12(\mathrm{~s}, 1 \mathrm{H}, \mathrm{NH}$ of indole $), 11.15(\mathrm{~s}, 1 \mathrm{H}, \mathrm{NH}$ of hydrazinecarbothioamide moiety) ppm; Anal. Calcd for $\mathrm{C}_{16} \mathrm{H}_{13} \mathrm{~N}_{4} \mathrm{OSCl}$ : C, 55.73; H, 3.77; N, 16.25 Found: C, 55.60; H, 3.72; N, 16.28\%; MS: $[\mathrm{M}]^{+}$at $\mathrm{m} / \mathrm{z} 344.5$.

Compound $31 \mathrm{IR}\left(\mathrm{KBr}, \mathrm{cm}^{-1}\right)$ : 3432(N-H stretching of indole), 3237(N-H stretching of hydrazinecarbothioamide moiety), $1700(\mathrm{C}=\mathrm{O}$ str $), 1156(\mathrm{C}=\mathrm{S}$ str $)$; ${ }^{1} \mathrm{HNMR}\left(400 \mathrm{MHz}, \mathrm{DMSO}-\mathrm{d}_{6}\right): \delta 2.28(\mathrm{~s}, 3 \mathrm{H}, \mathrm{CH} 3), 6.93\left(\mathrm{~d}, 1 \mathrm{H}, \mathrm{C}_{4} \mathrm{H}\right.$ proton), 7.51(d, $1 \mathrm{H} \mathrm{C} \mathrm{C}_{6} \mathrm{H}$ proton), 7.78 (d, $1 \mathrm{H} \mathrm{C} \mathrm{C}_{7} \mathrm{H}$ of indole), 7.54-7.72 $(\mathrm{m}, 4 \mathrm{H}, \mathrm{Ar}-$ $\mathrm{H}), 12.28(\mathrm{br}, 1 \mathrm{H},-\mathrm{NH}-\mathrm{Ar}), 11.12(\mathrm{~s}, 1 \mathrm{H}, \mathrm{NH}$ of indole $), 11.15(\mathrm{~s}, 1 \mathrm{H}, \mathrm{NH}$ of hydrazinecarbothioamide moiety) ppm ; Anal. Calcd for $\mathrm{C}_{16} \mathrm{H}_{13} \mathrm{~N}_{4} \mathrm{OSBr}$ : C, 49.35; H, 3.34; N, 14.39 Found: C, 49.40; H, 3.37; N, $14.34 \% ; \mathrm{MS}^{4}:[\mathrm{M}]^{+}$at $\mathrm{m} / \mathrm{z} 389$.

Compound 4a. IR $\left(\mathrm{KBr}, \mathrm{cm}^{-1}\right): 3452\left(\mathrm{NHstr}, \mathrm{ArNH}_{2}\right), 3320(\mathrm{NH}$ str, CONH), $1060(\mathrm{C}=\mathrm{Sstr}), 1650(\mathrm{C}=\mathrm{N}) .{ }^{1} \mathrm{HNMR}(\mathrm{DMSO}) \delta \mathrm{ppm}: 6.76-7.53(\mathrm{~m}$ $4 \mathrm{H}, \mathrm{Ar}-\mathrm{H}), 4.8\left(\mathrm{~s}, 2 \mathrm{H}, \mathrm{NH}_{2}\right), 7.01(\mathrm{~s}, 1 \mathrm{H}$, cyclic NNHCS $), 8.5(\mathrm{~s}, 1 \mathrm{H}$, cyclic CONH). Anal. Calcd. for $\mathrm{C}_{9} \mathrm{H}_{8} \mathrm{~N}_{4}$ OS: C, $49.08, \mathrm{H}, 3.66, \mathrm{~N}, 25.44$, Found: $\mathrm{C}$, 49.25, H, 3.67, N, 25.47.

Compound 4b. IR ( $\left.\mathrm{KBr}, \mathrm{cm}^{-1}\right): 3450\left(\mathrm{NH}\right.$ str, $\left.\mathrm{ArNH}_{2}\right), 3316$ (NH str, $\mathrm{CONH}), 1062\left(\mathrm{C}=\mathrm{S}\right.$ str), $1647 \quad(\mathrm{C}=\mathrm{N}), 735(\mathrm{Ar}-\mathrm{Cl}) .{ }^{1} \mathrm{HNMR}(\mathrm{DMSO}) \delta \mathrm{ppm}$ 6.66-7.73 (m, 8H, Ar-H), $5.2\left(\mathrm{~s}, 2 \mathrm{H}, \mathrm{NH}_{2}\right), 12.14$ (s, 1H, NNHCS). Anal Calcd. for $\mathrm{C}_{15} \mathrm{H}_{11} \mathrm{ClN}_{4} \mathrm{OS}$ : C, 54.46, H, 3.35, N, 16.94, Found: C, 54.27, H, $3.34, \mathrm{~N}, 16.96$.

Compound 4c. IR $\left(\mathrm{KBr}, \mathrm{cm}^{-1}\right)$ : $3455\left(\mathrm{NH}\right.$ str, $\left.\mathrm{ArNH}_{2}\right), 3318$ (NH str, $\mathrm{CONH}), 1068(\mathrm{C}=\mathrm{S}$ str $), 1654(\mathrm{C}=\mathrm{N}), 825(\mathrm{Ar}-\mathrm{Br}) .{ }^{1} \mathrm{HNMR}(\mathrm{DMSO}) \delta \mathrm{ppm}$ 6.70-7.68 (m, 8H, Ar-H), $5.4\left(\mathrm{~s}, 2 \mathrm{H}, \mathrm{NH}_{2}\right), 12.01(\mathrm{~s}, 1 \mathrm{H}, \mathrm{NNHCS})$. Anal. Calcd. for $\mathrm{C}_{15} \mathrm{H}_{11} \mathrm{~N}_{4} \mathrm{OSBr}$ : C, 49.01, H, 2.95, N, 14.93, Found: C, 49.19, H, 2.96, N, 14.96.

Compound 4d. IR $\left(\mathrm{KBr}, \mathrm{cm}^{-1}\right) 3450\left(\mathrm{NH}\right.$ str, $\left.\mathrm{ArNH}_{2}\right), 3310$ (NH str, $\mathrm{CONH}), 1080\left(\mathrm{C}=\mathrm{S}\right.$ str), $1667(\mathrm{C}=\mathrm{N}), 730(\mathrm{Ar}-\mathrm{Cl}) .{ }^{1} \mathrm{HNMR}$ (DMSO) $\delta \mathrm{ppm}$ 6.76-7.53 (m, 3H, Ar-H), 4.8 (s, 2H, NH $), 7.01(\mathrm{~s}, 1 \mathrm{H}$, cyclic NNHCS), 8.5 (s, $1 \mathrm{H}, \mathrm{CONH}$ ). Anal. Calcd. for $\mathrm{C}_{9} \mathrm{H}_{7} \mathrm{~N}_{4} \mathrm{ClN}_{4} \mathrm{OS}: \mathrm{C}, 42.44, \mathrm{H}, 2.77, \mathrm{~N}, 22.00$, Found: C, 42.64, H, 2.78, N, 22.03.

Compound 4e. IR $\left(\mathrm{KBr}, \mathrm{cm}^{-1}\right): 3453(\mathrm{NH}$ str, $\mathrm{ArNH}), 3322$ (NH str, $\mathrm{CONH}), 1082\left(\mathrm{C}=\mathrm{S}\right.$ str), $1666(\mathrm{C}=\mathrm{N}), 715-730(\mathrm{Ar}-\mathrm{Cl}) .{ }^{1} \mathrm{HNMR}(\mathrm{DMSO}) \delta$ ppm: 6.22-7.68, (m, 7H, Ar-H), $5.8\left(\mathrm{~s}, 2 \mathrm{H}, \mathrm{NH}_{2}\right), 12.11(\mathrm{~s}, 1 \mathrm{H}, \mathrm{NHCS})$. Anal Calcd. for $\mathrm{C}_{15} \mathrm{H}_{10} \mathrm{Cl}_{2} \mathrm{~N}_{4} \mathrm{OS}$ : C, 49.33, H, 2.76, N, 15.34, Found: C, 49.52, H, $2.75, \mathrm{~N}, 15.36$.

Compound 4f. IR ( $\left.\mathrm{KBr}, \mathrm{cm}^{-1}\right): 3460$ (NHstr, ArNH2), 3323 (NH str, $\mathrm{CONH}), 1072(\mathrm{C}=\mathrm{Sstr}), 1676(\mathrm{C}=\mathrm{N}), 725$ (Ar-Cl) 855 (Ar-Br). ${ }^{1} \mathrm{HNMR}$ (DMSO) $\delta$ ppm: 7.01-8.02, (m, 7H, Ar-H), $5.8\left(\mathrm{~s}, 2 \mathrm{H}, \mathrm{NH}_{2}\right), 12.11(\mathrm{~s}, 1 \mathrm{H}$, NNHCS). Anal. Calcd. for $\mathrm{C}_{15} \mathrm{H}_{10} \mathrm{ClN}_{4} \mathrm{OSBr}$ : C, 43.98, H, 2.46, N, 13.68, Found: C, 43.77, H, 2.47, N, 13.66 .

Compound 4g. IR $\left(\mathrm{KBr}, \mathrm{cm}^{-1}\right): 3464\left(\mathrm{NHstr}, \mathrm{ArNH}_{2}\right), 3324$ (NH str, $\mathrm{CONH}), 1070(\mathrm{C}=\mathrm{Sstr}), 1673(\mathrm{C}=\mathrm{N}), 875(\mathrm{Ar}-\mathrm{Br}) .{ }^{1} \mathrm{HNMR}(\mathrm{DMSO}) \delta \mathrm{ppm}$ :
6.61-7.42, (m, 3H, Ar-H), 4.8 (s, 2H, NH $), 12.01$ (s, 1H,NNHCS), 8.7 (s, 1H, cyclic $\mathrm{CONH}$ ). Anal. Calcd for $\mathrm{C}_{9} \mathrm{H}_{7} \mathrm{BrN}_{4} \mathrm{OS}$ : C, 36.14, H, 2.36, N, 18.73, Found: C, 36.35, H, 2.37, N, 18.75.

Compound 4h. IR ( $\left.\mathrm{KBr}, \mathrm{cm}^{-1}\right): 3468$ (NHstr, $\left.\mathrm{ArNH}_{2}\right), 3334$ (NH str, $\mathrm{CONH}), 1080(\mathrm{C}=\mathrm{Sstr}), 1677(\mathrm{C}=\mathrm{N}), 885(\mathrm{Ar}-\mathrm{Br}), 745{ }^{2}(\mathrm{Ar}-\mathrm{Cl}) .{ }^{1} \mathrm{HNMR}$ (DMSO) $\delta$ ppm: 7.01-8.06, (m, 7H, Ar-H), 5.28 (s, 2H, NH2), $12.21(\mathrm{~s}, 1 \mathrm{H}$, NNHCS). Anal. Calcd. for $\mathrm{C}_{15} \mathrm{H}_{10} \mathrm{BrN}_{4} \mathrm{OSCl}$ : C, 43.98, H, 2.46, N, 13.68, Found: C, 43.79, H, 2.47, N, 13.65.

Compound 5a. IR ( $\left.\mathrm{KBr}, \mathrm{cm}^{-1}\right): 3430$ (NHstr of indole), 3233 (NHstr of thiosemicarbazone moiety), $1668\left(\mathrm{C}=\right.$ Ostr), 1135 (C=Sstr). ${ }^{1} \mathrm{HNMR}$ (DMSO) $\delta$ ppm: 12.49 (s, $2 \mathrm{H}, \mathrm{NH}_{2}$ of thiosemicarbazone moiety), 11.03 (s, $1 \mathrm{H} \mathrm{NH}$ str of thiosemicarbazone moiety), 6.80-7.80 (m, 4H, Ar- $\mathrm{H}), 3.44$ (br s, $2 \mathrm{H}, \mathrm{N}_{-} \mathrm{CH}_{2}-\mathrm{N}$ proton), $2.48(\mathrm{~m}, 4 \mathrm{H}), 1.8(\mathrm{~s}, 4 \mathrm{H})$. Anal. Calcd. for $\mathrm{C}_{14} \mathrm{H}_{17} \mathrm{~N}_{5} \mathrm{O}_{2} \mathrm{~S}: \mathrm{C}, 52.65, \mathrm{H}$, 5.37, N, 21.93, Found: C, 52.85, H, 5.38, N, 21.95 .

Compound 5b. IR ( $\left.\mathrm{KBr}, \mathrm{cm}^{-1}\right): 3432$ (NHstr of indole), 3234 (NHstr of thiosemicarbazone moiety), 1672 (C=Ostr), 1133 (C=Sstr), 735 (Ar$\mathrm{Cl}$ ). ${ }^{1} \mathrm{HNMR}$ (DMSO) $\delta \mathrm{ppm}$ : 12.52-11.29 (s, 2H NH of thiosemicarbazone moiety), 6.40-7.27 (m, 8H, Ar- $\mathrm{H}$ ), 4.03 (br s, $2 \mathrm{H}, \mathrm{N}-\mathrm{CH}_{2}-\mathrm{N}$ proton), 2.24 (m, $4 \mathrm{H}), 1.50$ (s, 4H). Anal. Calcd. for $\mathrm{C}_{20} \mathrm{H}_{20} \mathrm{ClN}_{5} \mathrm{O}_{2} \mathrm{~S}: \mathrm{C}, 55.87, \mathrm{H}, 4.69, \mathrm{~N}, 16.29$, Found: C, 55.68, H, 4.68, N, 16.27 .

Compound 5c. IR ( $\left.\mathrm{KBr}, \mathrm{cm}^{-1}\right): 3434$ (NHstr of indole), 3237 (NHstr of thiosemicarbazone moiety), $1662(\mathrm{C}=\mathrm{Ostr}), 1127(\mathrm{C}=\mathrm{Sstr}), 855$ (ArBr). ${ }^{1} \mathrm{HNMR}$ (DMSO) $\delta \mathrm{ppm}$ : 12.42-11.19 (s, 2H NH of thiosemicarbazone moiety), 6.30-7.37 (m, 8H, Ar-H), 4.05 (br s, $2 \mathrm{H}, \mathrm{N}-\mathrm{CH}_{2}-\mathrm{N}$ proton), $2.14(\mathrm{~m}$, $4 \mathrm{H}), 1.70(\mathrm{~s}, 4 \mathrm{H})$. Anal. Calcd. for $\mathrm{C}_{20} \mathrm{H}_{20} \mathrm{BrN}_{5} \mathrm{O}_{2} \mathrm{~S}: \mathrm{C}, 50.64, \mathrm{H}, 4.25, \mathrm{~N}, 14.76$, Found: C, 50.84, H, 4.26, N, 14.78 .

Compound 5d. IR ( $\left.\mathrm{KBr}, \mathrm{cm}^{-1}\right): 3435$ (NHstr of indole), 3236 (NHstr of thiosemicarbazone moiety), $1672(\mathrm{C}=\mathrm{Ostr}), 1137(\mathrm{C}=\mathrm{Sstr}), 725-732$ (Ar$\mathrm{Cl}$ ). ${ }^{1} \mathrm{HNMR}$ (DMSO) $\delta \mathrm{ppm}$ : 12.32-11.09 (s, 2H NH of thiosemicarbazone moiety), 6.50-7.88 (m, 7H, Ar- $\mathrm{H}$ ), 4.02 (br s, $2 \mathrm{H}, \mathrm{N}-\mathrm{CH}_{2}-\mathrm{N}$ proton), 2.24 (m, $4 \mathrm{H}), 1.57(\mathrm{~s}, 4 \mathrm{H})$. Anal. Calcd. for $\mathrm{C}_{20} \mathrm{H}_{19} \mathrm{Cl}_{2} \mathrm{~N}_{5} \mathrm{OS}: \mathrm{C}, 53.58, \mathrm{H}, 4.27, \mathrm{~N}, 15.62$, Found: C, 53.78, H, 4.28, N, 15.64.

Compound 5e. IR $\left(\mathrm{KBr}, \mathrm{cm}^{-1}\right): 3433$ (NHstr of indole), 3234 (NHstr of thiosemicarbazone moiety), $1674(\mathrm{C}=$ Ostr), $1135(\mathrm{C}=\mathrm{Sstr}), 742(\mathrm{Ar}-\mathrm{Cl}), 885$ (Ar-Br). ${ }^{1} \mathrm{HNMR}$ (DMSO) $\delta$ ppm: 12.52-11.29 (s, 2H NH of thiosemicarbazone moiety), 7.01-7.70 (m, 7H, Ar-H), 4.04 (br s, $2 \mathrm{H}, \mathrm{N}-\mathrm{CH}_{2}-\mathrm{N}$ proton), 2.25 (m, $4 \mathrm{H}), 1.59(\mathrm{~s}, 4 \mathrm{H})$. Anal. Calcd. for $\mathrm{C}_{20} \mathrm{H}_{10} \mathrm{BrClN}_{5} \mathrm{OS}$ : C, 48.74, H, 3.89, N, 14.21, Found: C, 48.94, H, 3.88, N, 14.23.

Compound 5f. IR ( $\left.\mathrm{KBr}, \mathrm{cm}^{-1}\right)$ : 3431(NH str of indole), 3233 (NHstr of thiosemicarbazone moiety), $1666(\mathrm{C}=$ Ostr), $1131(\mathrm{C}=\mathrm{Sstr}), 732(\mathrm{Ar}-\mathrm{Cl})$. ${ }^{1} \mathrm{HNMR}$ (DMSO) $\delta \mathrm{ppm}: 12.09\left(\mathrm{~s}, 2 \mathrm{H}, \mathrm{NH}_{2}\right.$ of thiosemicarbazone moiety), 11.08 (s, 1H NHstr of thiosemicarbazone moiety), 6.20-7.03 (m, 3H, Ar-H), 3.64 (br s, $2 \mathrm{H}, \mathrm{N}-\mathrm{CH}_{2}-\mathrm{N}$ proton), $2.58(\mathrm{~m}, 4 \mathrm{H}), 1.9(\mathrm{~s}, 4 \mathrm{H})$. Anal. Calcd. for $\mathrm{C}_{14} \mathrm{H}_{16} \mathrm{ClN}_{5} \mathrm{OS}: \mathrm{C}, 49.77, \mathrm{H}, 4.77, \mathrm{~N}, 20.73$, Found: C, 49.98, H, 4.76, N, 20.75.

Compound 6a. IR $\left(\mathrm{KBr}, \mathrm{cm}^{-1}\right): 3350$ (NHstr of indole), 1590-1654 (C=N), 1131 (C=Sstr). ${ }^{1} \mathrm{HNMR}$ (DMSO) $\delta$ ppm: 6.60-7.53 (m, 4H, Ar-H), 4.4 (s, $2 \mathrm{H}$ $\mathrm{NH}$ of indole), 7.90 (s, $1 \mathrm{H}, \mathrm{NNHCS}$ ). Anal. Calcd. for $\mathrm{C}_{9} \mathrm{H}_{6} \mathrm{~N}_{4} \mathrm{~S}: \mathrm{C}, 53.45, \mathrm{H}$, 2.29, N, 27.70, Found: C, 53.66, H, 2.28, N, 27.72.

Compound 6b. IR $\left(\mathrm{KBr}, \mathrm{cm}^{-1}\right)$ : 3352 (NHstr of indole), 1580-1653 (C=N), $1132\left(\mathrm{C}=\right.$ Sstr). ${ }^{1} \mathrm{HNMR}$ (DMSO) $\delta \mathrm{ppm}: 6.66-7.58$ (m, 3H, Ar-H), $4.6(\mathrm{~s}, 2 \mathrm{H}$ $\mathrm{NH}$ of indole), 7.11 (s, $1 \mathrm{H}, \mathrm{NNHCS}$ ). Anal. Calcd. for $\mathrm{C}_{9} \mathrm{H}_{5} \mathrm{ClN}_{4} \mathrm{~S}: \mathrm{C}, 45.67, \mathrm{H}$, 2.13, N, 23.67, Found: C, 45.87, H, 2.14, N, 23.69.

Compound 6c. IR ( $\left.\mathrm{KBr}, \mathrm{cm}^{-1}\right)$ : 3355 (NHstr of indole), 1592-1664 (C=N), 1134 (C=Sstr). ${ }^{1} \mathrm{HNMR}$ (DMSO) $\delta$ ppm: 6.70-7.83 (m, 3H, Ar-H), 4.7 (s, 2H $\mathrm{NH}$ of indole), 7.70 (s, 1H, NNHCS). Anal. Calcd. for $\mathrm{C}_{9} \mathrm{H}_{5} \mathrm{BrN}_{4} \mathrm{~S}: \mathrm{C}, 38.45$, H, 1.79, N, 19.93, Found: C, 38.67, H, 1.77, N, 19.96.

\section{Antimicrobial activity}

Antibacterial activity. Synthesized compounds (3a-l) were screened for their antibacterial activity against Gram-positive bacteria Bacillus cereus (MTCC 0430) and Gram-negative bacteria Enterobacter aerogenes (MTCC 2824) and compounds (4b, 4d, 4g, 4h, 5a, 5b, 5d, 5f, 6a, 6b) against Escherichia coli, Staphylococcus aureus, and K. pneumoniae by the Agar Well 
Diffusion method $.5 \mathrm{ml}$ aliquot of nutrient broth was inoculated with the test organism and incubated at $37^{\circ} \mathrm{C}$ for 24 hours. Sterile nutrient agar plates were also prepared and holes of $5 \mathrm{~mm}$ diameter were cut using a sterile cork borer ensuring proper distribution. The test organisms after 24 hours of incubation were spread onto separate agar plates. The chemical compounds were either dissolved in DMSO or DMF at a particular concentration or poured into appropriately labelled holes using a pipette in aseptic conditions. A hole containing DMSO or DMF served as a control. The plates were left at room temperature for two hours to allow the diffusion of the sample followed by incubation at $37^{\circ} \mathrm{C}$ for 24 hours in inverted position. The antimicrobial activity was determined by measuring the diameter of the zone (mm) showing complete inhibition with respect to control (DMSO and DMF)(TABLE V; VI).

Table V: Effect of chemical compounds (3a-1) on bacterial growth.

\begin{tabular}{|c|c|c|c|c|}
\hline $\begin{array}{c}\text { Compound } \\
\text { Name }\end{array}$ & $\mathbf{R}$ & $\mathbf{R}_{\mathbf{1}}$ & $\begin{array}{c}\text { Diameter of Zone (mm) of } \\
\text { Inhibition against Bacillus cereus } \\
\text { (MTCC 0430) }\end{array}$ & $\begin{array}{c}\text { Diameter of Zone (mm) of Inhibition } \\
\text { against Enterobacter aerogenes. (MTCC } \\
\text { 2824) }\end{array}$ \\
\hline $3 \mathrm{a}$ & $\mathrm{H}$ & $\mathrm{H}$ & 13 & 03 \\
\hline $3 \mathrm{~b}$ & $5-\mathrm{Cl}$ & $\mathrm{H}$ & 11 & 05 \\
\hline $\mathbf{3 c}$ & $\mathbf{5 - B r}$ & $\mathbf{H}$ & $\mathbf{2 5}$ & 07 \\
\hline $3 \mathrm{~d}$ & $\mathrm{H}$ & $4-\mathrm{Cl}_{6} \mathrm{H}_{4}$ & 04 & 03 \\
\hline $3 \mathrm{e}$ & $5-\mathrm{Cl}$ & $4-\mathrm{Cl} \mathrm{C}_{6} \mathrm{H}_{4}$ & 06 & 04 \\
\hline $3 \mathrm{f}$ & $5-\mathrm{Br}$ & $4-\mathrm{Cl} \mathrm{C}_{6} \mathrm{H}_{4}$ & 05 & 06 \\
\hline $3 \mathrm{~g}$ & $\mathrm{H}$ & $4-\mathrm{Br} \mathrm{C}_{6} \mathrm{H}_{4}$ & 15 & 04 \\
\hline $3 \mathrm{~h}$ & $5-\mathrm{Cl}$ & $4-\mathrm{Br}_{6} \mathrm{H}_{4}$ & 09 & 03 \\
\hline $3 \mathrm{i}$ & $5-\mathrm{Br}$ & $4-\mathrm{Br} \mathrm{C}_{6} \mathrm{H}_{4}$ & 09 & 08 \\
\hline $3 \mathrm{j}$ & $\mathrm{H}$ & $4-\mathrm{CH}_{3} \mathrm{C}_{6} \mathrm{H}_{4}$ & 09 & 06 \\
\hline $3 \mathrm{k}$ & $5-\mathrm{Cl}$ & $4-\mathrm{CH}_{3} \mathrm{C}_{6} \mathrm{H}_{4}$ & 08 & 05 \\
\hline 31 & $5-\mathrm{Br}$ & $4-\mathrm{CH}_{3} \mathrm{C}_{6} \mathrm{H}_{4}$ & 17 & 20 \\
\hline$(\mathrm{DMSO})$ & - & - & 20 & 03 \\
\hline
\end{tabular}

Among the compounds tested, $3 \mathrm{c}$ is found to be active against bacteria Bacillus cereus and $4 \mathrm{~b}, 4 \mathrm{~g}, 4 \mathrm{~h}, 5 \mathrm{~b}, 5 \mathrm{~d}, 5 \mathrm{f}, 6 \mathrm{a}$ and $6 \mathrm{~b}$ are found to be active against $E$ coli, S. aureus K. pneumoniae at $500 \mu \mathrm{g} / \mathrm{ml}$ concentration.

Antifungal activity. It was carried out against $A$. alternata by measuring the zone of inhibition in $\mathrm{mm}$. The antimicrobial activity was performed by cup plate method at concentration $500 \mu \mathrm{g} / \mathrm{ml}$ and $250 \mu \mathrm{g} / \mathrm{ml}$ as reported in TABLE VI. Czapex Dox agar was employed as culture medium and DMF was used as solvent control for antifungal activity. $4 \mathrm{~d}, 4 \mathrm{~g}, 5 \mathrm{f}$ and $6 \mathrm{a}$ are found to be active against A. alternata.

Table VI: Effect of chemical compounds 4, 5 and 6 on bacterial growth.

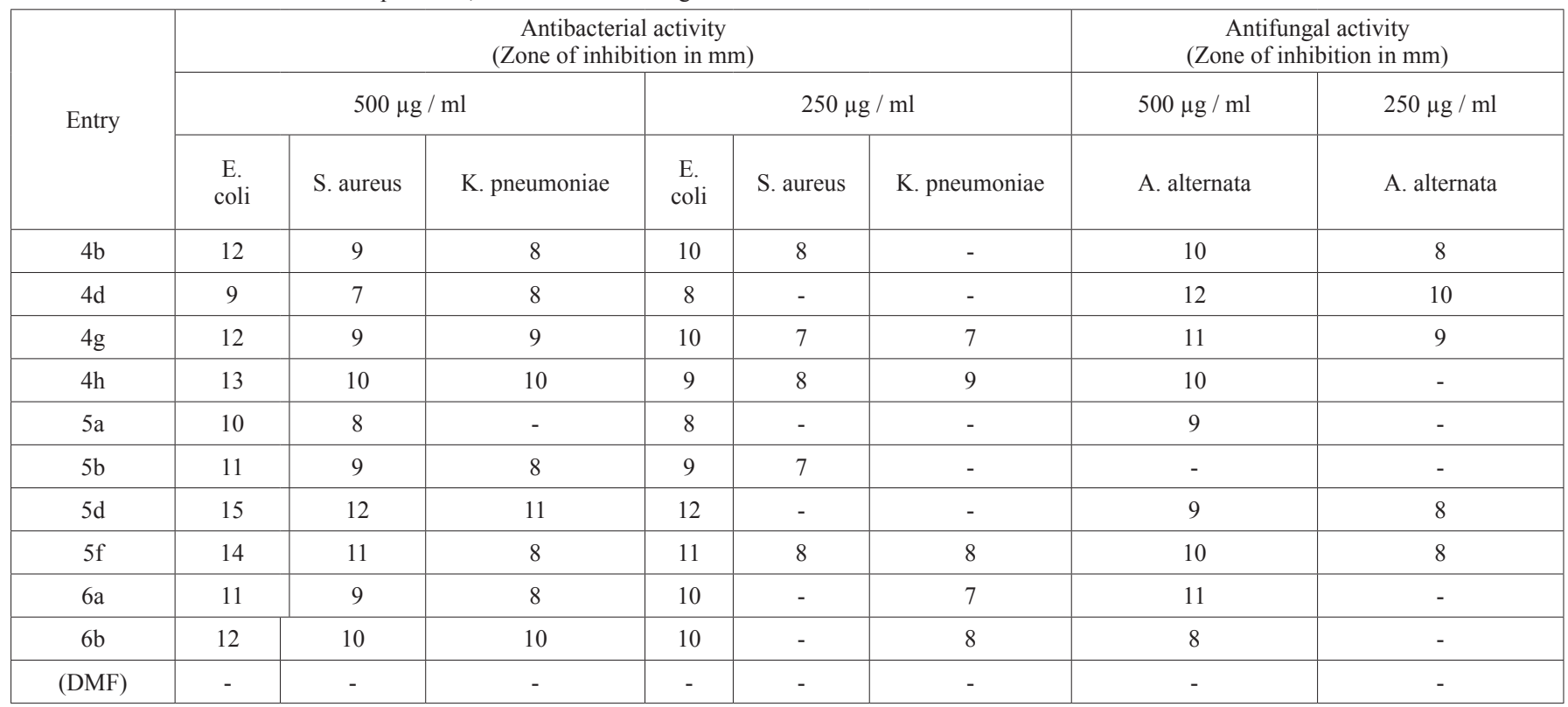

\section{ACKNOWLEDGEMENTS}

Authors are thankful to the Dean, Prof. P K Das and to the Head of the Department, Prof. K Singh (Science and Humanities), FET, MITS, for providing necessary research facilities in the department. Financial assistance from FET, MITS is gratefully acknowledged. We are also thankful to SAIF Punjab University, Chandigarh for the elemental and spectral analyses. 


\section{REFERENCES}

1. V. Krchňák, M. W. Holladay, Chem. Rev. 61, 102, (2002).

2. L. A. Thompson, J. A. Ellman, Chem. Rev. 96, 555, (1996).

3. N. K. Terrett, M. Gardner, D. W. Gordon, R. J. Kobylecki, J. Steele, Tetrahedron 51, 8135, (1995).

4. M. Gracia, Valverde and T. Torroba, Molecules 10, 318, (2005).

5. T. R. Bal, B. Anand, P. Yogeeswari, D. Sriram, Bioorg. Med. Chem. Lett. 15 (20), 4451, (2005).

6. S. N. Pandeya, S.Smitha, M. Jyoti, S.K. Sridhar, Acta Pharmaceutica 55 (1), 27, (2005).

7. I. Chiyanzu, C. Clarkson, P.J. Smith, J. Lehman, J. Gut, P. J. Rosenthal, K. Chibale, Bioorg. Med. Chem. 13 (9), 3249, (2005).

8. B. B. Baldaniya, P. K. Patel, E- J. Chem. 6(3), 673, (2009).

9. A. Solankee, K. Kapadia, Ind. J. Chem. 46B, 1707, (2007).

10. F. D. Settimo, G. Primofiore, J. Med. Chem. 44, 316, (2001).

11. M. S. S. Palanki, H. Akiyama J. Med.Chem. 51, 1546, (2008).

12. Z. El- Gendy, J. M. Morsy, Phosphorus, Sulfur, and Silicon 178, 2055, (2003).

13. H. Neunhoeffer, In Comprehensive Heterocyclic chemistry, A.R Katritzky, C.W. Rees Ed. Pergamon, Oxford, 1984, 3, pp 385.

14. S. N. Pandeya, R. Kumar, A.K Pathak, G.Nath, Der Pharma Chemica 2(2), 257-266, (2010).

15. R. M. Abdel-Rahman, M. S. I.T. Makki and W. A. Baker Bawazir E-Journal of Chemistry, 7(S1), S93, (2010).

16. P. Mullick, S. A. Khan, T. Begum, S. Verma, D. Kaushik and O. Alamacta, Poloniae Pharmaceutica Ñ Drug Research 66 (4), 379, (2009).

17. S. M. Shelke, S. H. Bhosale, Bioorg. Med. Chem. Lett. 20, 4661-4664, (2010).

18. D. Villemin, M. Hammadi, M. Hachemi and N. Bar, Molecules 6, 831, (2001).
19. A. Loupy, Microwaves in organic syntheses, Wiley-Vch, Weinheim, 2006.

20. C.O. Kappe and Stadler, Microwaves in Organic and Medicinal chemistry, Wiley-VCH, Weinheim, 2005.

21. C. J. Li and T.H. Chan, Organic reactions in aqueous media, John Wiley and Sons, New York, 1997.

22. A. Dandia, H. Sachdeva, R. Singh J. Chem. Res. (S) 272, (2000).

23. A. Dandia, R. Singh, H. Sachdeva, K. Arya, J. Fluorine chem. 111, 61, (2001).

24. A. Dandia, H. Sachdeva, R. Singh Synth. Commun. 31(12), 1879, (2001).

25. A. Dandia, R. Singh, H. Sachdeva, R. Gupta, S. Paul J. Chin. Chem. Soc. 50,273, (2003).

26. A. Dandia, H. Sachdeva, R. Singh, C. S. Sharma, Ind. J. Chem. 42(B), 140, (2003).

27. H. Sachdeva, Ind. J. Het. Chem. 18(3), 315, (2009).

28. H. Sachdeva, D. Dwivedi and S. Khaturia, Res. J. Pharm. Biolog. Chem. Sci. 2(2), 213, (2011).

29. S.N. Pandeya, D. Sriram, E. Declercq, G. Nath, Eur. J. Pharm. Sci. 9, 25, (1999).

30. M. C. Pirrung, S.V. Panasare, K. D. Sharma, K. Keith, E. R. Kern, J. Med. Chem. 48, 3045, (2005).

31. H.S.M. Seleem, M. EI. Behairy, M. M. Mashaly, H.H. Mena, J. Serb. Chem. Soc. 67, 243, (2002).

32. C. D. Wang, X. Z. Shi, Y. H. Feng, Synth. Commun. 29(17), 3057, (1999).

33. N. Karali, Eur. J. Med.Chem. 37, 909, (2002).

34. F. E. Anderson, C. J. Duca, J.V. Scudi, J Am. Chem. Soc. 73, 4967, (1951). 